\title{
Global impact of smoke aerosols from landscape fires on climate and the Hadley circulation
}

\author{
M. G. Tosca ${ }^{1, *}$, J. T. Randerson ${ }^{1}$, and C. S. Zender ${ }^{1}$ \\ ${ }^{1}$ Department of Earth System Science, University of California, Irvine, CA 92697, USA \\ * now at: NASA Jet Propulsion Laboratory, California Institute of Technology, Pasadena, CA 91109, USA
}

Correspondence to: M. G. Tosca (michael.g.tosca@jpl.nasa.gov)

Received: 1 October 2012 - Published in Atmos. Chem. Phys. Discuss.: 25 October 2012

Revised: 12 April 2013 - Accepted: 24 April 2013 - Published: 24 May 2013

\begin{abstract}
Each year landscape fires across the globe emit black and organic carbon smoke particles that can last in the atmosphere for days to weeks. We characterized the climate response to these aerosols using an Earth system model. We used remote sensing observations of aerosol optical depth (AOD) and simulations from the Community Atmosphere Model, version 5 (CAM5) to optimize satellitederived smoke emissions for high biomass burning regions. Subsequent global simulations using the adjusted fire emissions produced AODs that were in closer agreement with surface and space-based measurements. We then used CAM5, which included radiative aerosol effects, to evaluate the climate response to the fire-aerosol forcing. We conducted two $52 \mathrm{yr}$ simulations, one with four sets of monthly cycling 1997-2009 fire emissions and one without. Fire emissions increased global mean annual AOD by $10 \%(+0.02)$ and decreased net all-sky surface radiation by $1 \%\left(1.3 \mathrm{~W} \mathrm{~m}^{-2}\right)$. Elevated AODs reduced global surface temperatures by $0.13 \pm 0.01{ }^{\circ} \mathrm{C}$. Though global precipitation declined only slightly, patterns of precipitation changed, with large reductions near the Equator offset by smaller increases north and south of the intertropical convergence zone (ITCZ). A combination of increased tropospheric heating and reduced surface temperatures increased equatorial subsidence and weakened the Hadley circulation. As a consequence, precipitation decreased over tropical forests in South America, Africa and equatorial Asia. These results are consistent with the observed correlation between global temperatures and the strength of the Hadley circulation and studies linking tropospheric heating from black carbon aerosols with tropical expansion.
\end{abstract}

\section{Introduction}

Climate is a primary driver of global and regional fire activity, and fires, in turn, influence climate on similar temporal and spatial scales by means of emissions of trace gases and aerosols and by modifying vegetation composition and structure (Marlon et al., 2008; Power et al., 2008; Bowman et al., 2009; Ward et al., 2012). Fire incidence was low outside of the tropics and subtropics during the last glacial maximum, coinciding with cool temperatures, but increased as global temperatures began rising around $12000 \mathrm{yr}$ ago (Power et al., 2008). During the last two millennia, fires decreased between AD 1 and 1750, during a period of gradual global cooling (Marlon et al., 2008). Subsequently, between 1750 and 1870, fire activity, inferred from charcoal records, rapidly increased, coinciding with a period of temperature increases but also when humans began exerting greater control on ecosystem processes through land management (Marlon et al., 2008). In the American Southwest, regionally large fire years over the last several centuries often followed dry winters preceded by several years of cool and wet conditions that allowed fuels to accumulate (Swetnam and Betancourt, 1998). In western North America, anthropogenic climate warming over the last several decades has increased the number of large wildland fires (Westerling et al., 2006) and also may have influenced burn severity and levels of fuel consumption (Turetsky et al., 2011). On interannual timescales, satellite observations of burned area and active-fire thermal anomalies provide evidence that the El Niño-Southern Oscillation and other climate modes modify fire activity considerably in tropical forest and savanna ecosystems (Spessa et al., 2005; van der Werf et al., 2008; Field et al., 2009; Fernandes et al., 2011; Chen et al., 2011). 
Feedback between climate and fires is possible because fires also modify climate through several different pathways. Fires have contributed to the accumulation of carbon dioxide and methane in the atmosphere in recent decades, for example, by enabling more rapid rates of land clearing in forest ecosystems (Crutzen et al., 1979; Langenfelds et al., 2002; Page et al., 2002). Fire emissions from deforestation fires were approximately $490 \mathrm{Tg} \mathrm{C} \mathrm{yr}^{-1}$ during 1997-2009 (van der Werf et al., 2010). This flux, which equals a quarter of all global fire emissions, represents a net source of $\mathrm{CO}_{2}$ because many forests are being permanently replaced by pastures and croplands. Fires have also contributed to tropical forest degradation during this period (i.e., the loss of trees and biomass in nearby forests not intentionally cleared), and although this flux is difficult to quantify, it likely represents another important source of carbon emissions (Morton et al., 2011). Fires also influence climate by inducing vegetation mortality, with longer-term effects on surface albedo and energy exchange as a consequence of post-fire vegetation succession (Myhre et al., 2005; Lyons et al., 2008; Liu and Randerson, 2008). Emissions of ozone precursors may have immediate consequences for radiative forcing (Ward et al., 2012) and also longer-term effects on canopy conductance and ecosystem carbon storage (Sitch et al., 2007).

In this study, we focus on another important climate driver: emissions of smoke aerosols. While the radiative effects of smoke aerosols from fires have been investigated for several decades (Kaufman et al., 1991; Penner et al., 1992; Chylek and Wong, 1995; Hansen et al., 1997; Ramanathan and Carmichael, 2008), as described below, important uncertainties remain with respect to the temporal and spatial magnitude of surface and top-of-atmosphere forcing caused by smoke from landscape fires (Reid et al., 2009). Even less is known about how this forcing subsequently modifies atmosphere and surface energy fluxes, cloud lifetimes, circulation characteristics, and regional to global scale temperature and precipitation patterns. Here we investigate the relationship between forcing and climate response to fires using a global Earth system model that includes direct and semidirect aerosol effects. In the remainder of the introduction we review recent work on smoke aerosol radiative forcing and relevant processes influencing large-scale climate interactions.

Black and organic carbon (BC and $\mathrm{OC}$ ) are primary constituents of smoke aerosols from landscape fires, with $\mathrm{BC}$ accounting for 5-10\% of the total particle mass and OC accounting for much of the remainder (Andreae and Merlet, 2001; Reid et al., 2005). Mahowald et al. (2011) estimate that approximately $60 \mathrm{Tg}$ of smoke is emitted from landscape fires each year. This constitutes $30 \%$ of the total black and organic smoke mass emitted globally each year (Lamarque et al., 2010). These aerosols alter the climate through the scattering and absorption of solar radiation, which simultaneously cools the surface and warms the atmospheric column (Penner et al., 1992; Hansen et al., 1997; Ramanathan and
Carmichael, 2008), and by modifying cloud properties (Penner et al., 1992; Ackerman et al., 2000). Bauer and Menon (2012) estimate that the direct radiative effect of smoke from grass fires, forest fires and agricultural waste burning is close to zero globally. This forcing, however, is the residual of larger regional and seasonal warming and cooling terms, with negative fluxes in tropical land and ocean regions and positive fluxes in polar regions. Jones et al. (2007) estimated the direct global radiative forcing from fire aerosols to be $-0.29 \mathrm{~W} \mathrm{~m}^{-2}$, leading to a global mean temperature decrease of $0.25^{\circ} \mathrm{C}$ in the Hadley Centre climate model and a forcing efficacy of 0.86 .

Accumulating evidence suggests that smoke-induced changes in net column shortwave radiation and interactions between smoke particles and cloud droplets can modify precipitation (Andreae et al., 2004; Rosenfeld, 2006; Rosenfeld et al., 2008; Andreae and Rosenfeld, 2008). Widespread convection suppression, the result of lowered surface temperatures and elevated atmospheric heating via $\mathrm{BC}$ absorption, increases vertical stratification, which inhibits both cloud formation and precipitation (Ackerman et al., 2000; Feingold et al., 2001; Tosca et al., 2010). Including smoke in climate simulations over the Amazon caused a change in monsoonal circulation in regions with aerosol optical depths greater than 0.3 (Zhang et al., 2009). In the Zhang et al. (2009) study, smoke heating increased surface pressure, decreased upward vertical velocity and reduced the lapse rate, the combination of which increased surface divergence. As a consequence, the onset of early autumn monsoonal rains was delayed. Analysis of satellite observations by Koren et al. (2004) provides support for this mechanism: areas with thick smoke over the Amazon had fewer clouds. The entrainment of microscopic smoke particles into clouds also acts to suppress precipitation by slowing the conversion of cloud drops into raindrops (Gunn and Phillips, 1957; Rosenfeld et al., 2008). Using satellite observations from the Tropical Rainfall Measuring Mission (TRMM) of smoke-polluted clouds over the Amazon, Rosenfeld (1999) detected ample water for rainfall, but a lack of precipitation due to numerous small water droplets. In contrast to the semi-direct aerosol effect described by Ackerman et al. (2000), where smokeinduced radiative heating limits the formation of trade cumulus clouds, Albrecht (1989) provided evidence that aerosols in marine stratocumulus regions increase cloudiness and decrease cloud droplet sizes, effectively limiting drizzle. Considering all of these effects together, contemporary aerosols, including smoke from landscape fires, likely weaken the hydrologic cycle (Ramanathan et al., 2001). Recent increases in tropical aerosols over the last half century from anthropogenic activity (Field et al., 2009) may offset the expected strengthening of the hydrologic cycle from global warming (Held and Soden, 2006).

In some areas, ingestion of smoke aerosols into ice-phase cumulonimbus clouds may increase local precipitation. In smoke-polluted cumulus clouds, the percentage of droplets 
above the freezing level is larger, which maximizes the lifetime and vertical size of the cloud and increases the intensity of downdrafts and precipitation rates (Rosenfeld et al., 2008). Koren et al. (2005) observed invigoration of convective clouds by biomass burning aerosols over the Atlantic Ocean. Taken together, these studies illustrate the uncertainties involved in understanding fire aerosol effects at the global scale. However, the inclusion of improved moist turbulence schemes and better representation of aerosol-cloud microphysical interactions in Earth system models (Bretherton and Park, 2009) provide unique opportunities to examine fire aerosol effects on regional and global climate.

Recent work suggests that the mean strength of the Hadley circulation is increasing (Mitas and Clement, 2005), and though most studies attribute this strengthening and expansion to higher surface temperatures (Lu et al., 2007; Quan et al., 2005), there is evidence that aerosols, especially black carbon and sulfate, play a role in altering the mean circulation (Yoshimori and Broccoli, 2009). Jones et al. (2007) suggest that increased atmospheric loading of biomass burning aerosols shifts the location of the inter-tropical convergence zone, and Allen et al. (2012b) argue that black carbon aerosol forcing helps explain the seasonality and extent of recent Hadley cell expansion. Specifically, black carboninduced heating of the lower troposphere at mid-latitudes significantly contributes to the observed poleward shift of the descending branch of the Hadley circulation (Allen et al., 2012a,b). Our work isolates the impact of fire aerosols on mean global circulation patterns using an Earth system model that includes direct and semi-direct aerosol effects. In addition, we quantify the impact of smoke aerosols on climate variables intrinsically linked to precipitation and radiation changes.

\section{Methods}

We used an Earth system model with interactive atmospheric chemistry to simulate climate with and without landscape fire aerosols. We first optimized black carbon (BC) and organic carbon (OC) emissions from fire by matching simulated aerosol optical depths (AODs) to observations and scaling emissions by regionally unique factors that best matched observed AODs in high biomass burning regions. We then performed two $52 \mathrm{yr}$ simulations with and without the adjusted fire aerosol emissions and assessed the impact of these aerosols on global temperature, precipitation and the mean Hadley circulation.

\subsection{Model and data description}

For our simulations we used the Community Earth System Model (CESM), version 1, initialized with the Community Atmosphere Model, version 5 (CAM5), and the single-layer ocean model (SOM) (Neale et al., 2010). The full chemistry model embedded in CAM5 for this experiment was the Model for Ozone and Related Chemical Tracers, version 4 (MOZART-4) (Emmons et al., 2010). Like previous versions of CAM (CAM3 and CAM4), this configuration (trop_mozart) includes direct and semi-direct aerosol radiative effects (Collins et al., 2004) and utilizes the bulk aerosol model (BAM) configuration (Rasch et al., 2001; Lamarque et al., 2012). The moist turbulence scheme in CAM5 replaces the dry turbulence scheme in previous versions and explicitly simulates cloud-radiation-turbulence interactions, allowing for a more realistic simulation of aerosol semi-direct effects in stratus clouds (Bretherton and Park, 2009). Also included in CAM5 are an improved shallow convection scheme and a revised cloud macrophysics scheme (Neale et al., 2010). The atmospheric chemistry component is now fully interactive and embedded within CAM5 and handles emissions of aerosols and trace gases and deposition of aerosols to snow, ice and vegetation. Our simulations did not use the Modal Aerosol Model (MAM) to simulate cloud indirect effects (Liu et al., 2012), with efforts still ongoing to improve the representation of these processes within CAM. Evaluating indirect effects on the climate response documented here is an important next step.

To estimate landscape fire emissions, we used gaseous and particulate fire emissions from the Global Fire Emissions Database, version 3 (GFEDv3) (van der Werf et al., 2010). Calculation of burned area in GFEDv3 is described by Giglio et al. (2010). Fuel loads and combustion completeness factors are estimated using a biogeochemical model and are combined with satellite-derived burned area estimates to derive total carbon emissions. Aerosol emissions are then estimated from total emissions using emissions factors for different biomes, drawing upon published emission factors from Andreae and Merlet (2001) that are updated annually. Akagi et al. (2011) have published an update to emission factors from Andreae and Merlet (2001) that were not available during the construction of GFEDv3, but likely will be incorporated in a future version of the GFED model. We used the Multi-angle Imaging SpectroRadiometer (MISR) Level 3 daily AOD product (MIL3MAE) and the Moderate Resolution Imaging Spectro-radiometer (MODIS) Level 3, Collection 5 monthly AOD product (MOD08 M3), to assist in scaling the GFED aerosol emissions.

We used ground-based Aerosol Robotic Network (AERONET) optical depth data (Holben et al., 1998) from 21 individual stations to evaluate our model simulations with adjusted emissions. We assessed the strength and spatial location of the Hadley circulation using horizontal and vertical wind velocities obtained from the European 
Centre for Medium-Range Weather Forecasting (ECMWF) interim Reanalysis product (ERA-interim) (Dee et al., 2011). Monthly ERA-interim data were available from 1989-2011 at a $0.75^{\circ} \times 0.75^{\circ}$ horizontal resolution with 60 vertical levels.

\subsection{Scaling fire emissions to achieve realistic AODs}

We forced an initial simulation of the CAM5-SOM configuration of CESM with monthly varying fire emissions from GFEDv3 during 1997-2009. Evidence from Ward et al. (2012) suggests that to accurately simulate observed aerosol optical depths, GFEDv3 smoke emissions need to be approximately doubled. Therefore, our initial simulations were forced with $2 \times$ GFEDv $3 \mathrm{BC}$ and $\mathrm{OC}$ emissions and $1 \times$ GFEDv $3 \mathrm{SO}_{2}$ emissions. Initialization datasets were produced using linear interpolation to re-grid the original GFEDv3 data $\left(0.5^{\circ} \times 0.5^{\circ}\right.$ spatial resolution) to the CAM5 resolution $\left(1.9^{\circ} \times 2.5^{\circ}\right)$. This study isolated the climate response to aerosols-only; we thus excluded altering nitrogen emissions as some molecules of $\mathrm{NO}_{2}$ act as precursors to ozone formation. Aerosols were injected into the lowest layer of the model, as evidence suggests that smoke injection above the boundary layer is rare (Val Martin et al., 2010; Tosca et al., 2011).

Comparison of the resulting CAM5-simulated AODs to observations from both MISR and MODIS revealed a low bias in biomass burning regions (Fig. S1). Some of the bias may be explained by a lack of an explicit parametrization of secondary aerosol condensation and coagulation processes in CAM5. Specifically, the emission factors we used from Andreae and Merlet (2001) may include measurements made prior to significant plume aging and condensation. Studies have shown that secondary aerosols constitute a significant fraction of the total aerosol mass within biomass burning plumes (Lee et al., 2008; Grieshop et al., 2009). For example, organic carbon aerosol concentrations increased by factors of 1.5 to 6 after 3 to $4 \mathrm{~h}$ of aging downwind of a prescribed fire in Georgia (Lee et al., 2008). It is also likely that the GFEDv3 inventory underestimated emissions contributions from small fires by as much as $35 \%$ (Randerson et al., 2012). Furthermore, there is some evidence that liquid cloud fraction and wet deposition rates are too high in CAM5 and that this contributes to increased wet aerosol deposition and thus low optical depth biases (Wang et al., 2013).

In the three major tropical burning regions of South America (SAM), southern Africa (SAF) and equatorial Asia (EAS) (Fig. 1), AODs were substantially lower than observations from MISR and MODIS (Fig. 2). For these regions, and also for boreal North America, we computed the scaling factor required to bring the AODs into agreement with the satellite time series. Our scaling factors apply only to direct aerosols emissions as we did not explicitly include any parametrization of secondary organic aerosol formation within fire plumes. We chose regions where fire aerosols
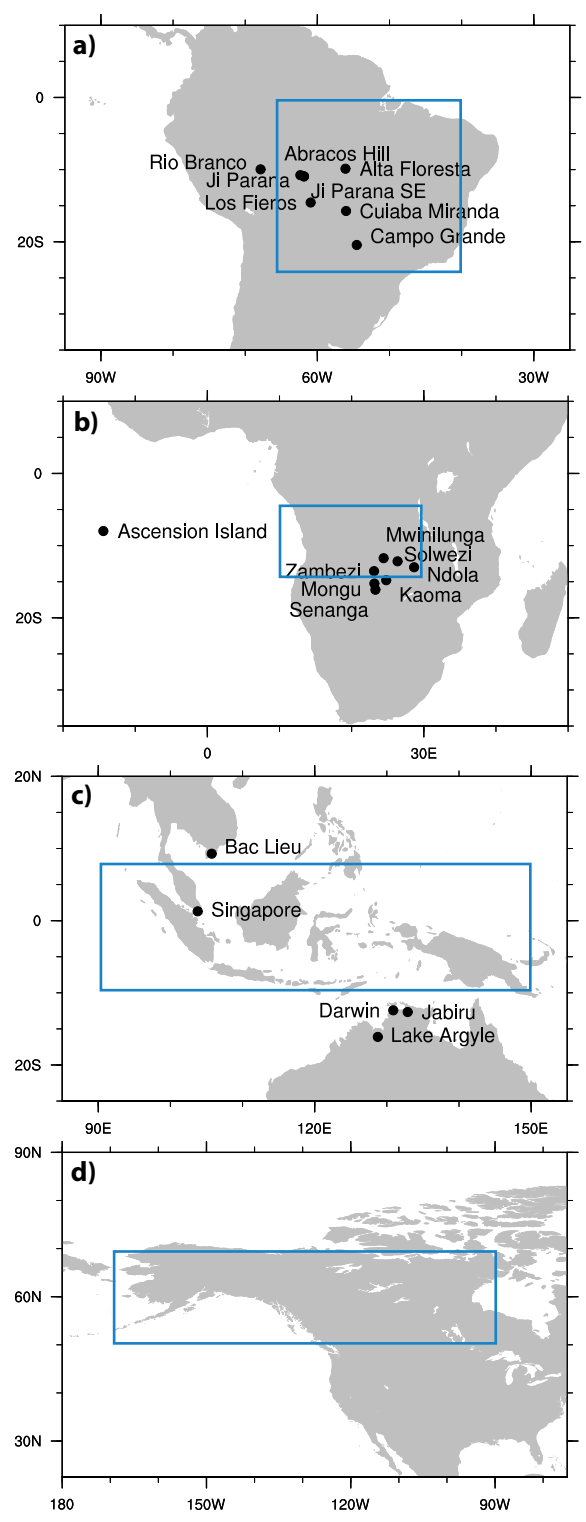

Fig. 1. Regional maps of AERONET stations (black dots) and MISR/MODIS scaling areas (blue boxes) for (a) South America (SAM), (b) southern Africa (SAF), (c) equatorial Asia (EAS) and (d) boreal North America (BNA). There were no suitable AERONET stations in BNA.

were the dominant contributor to the optical depth signal within CAM5, thereby increasing the likelihood of a monotonic relation between emissions and optical depth (Fig. S2). We chose SAM $\left(25^{\circ} \mathrm{S}-0 ; 65-40^{\circ} \mathrm{W}\right)$, SAF $\left(15-5^{\circ} \mathrm{S} ; 10\right.$ $\left.30^{\circ} \mathrm{E}\right)$, EAS $\left(10^{\circ} \mathrm{S}-7^{\circ} \mathrm{N} ; 90^{\circ} \mathrm{E}-150^{\circ} \mathrm{E}\right)$ and boreal North America (BNA; $50-70^{\circ} \mathrm{N} ; 170-90^{\circ} \mathrm{W}$ ) as our initial scaling regions. We then derived four regionally-specific mean scale factors by computing the ordinary least squares regression between the simulated AOD (independent variable) and the observed (dependent variable) for those months in the time series that cumulatively contributed to $80 \%$ of regional 


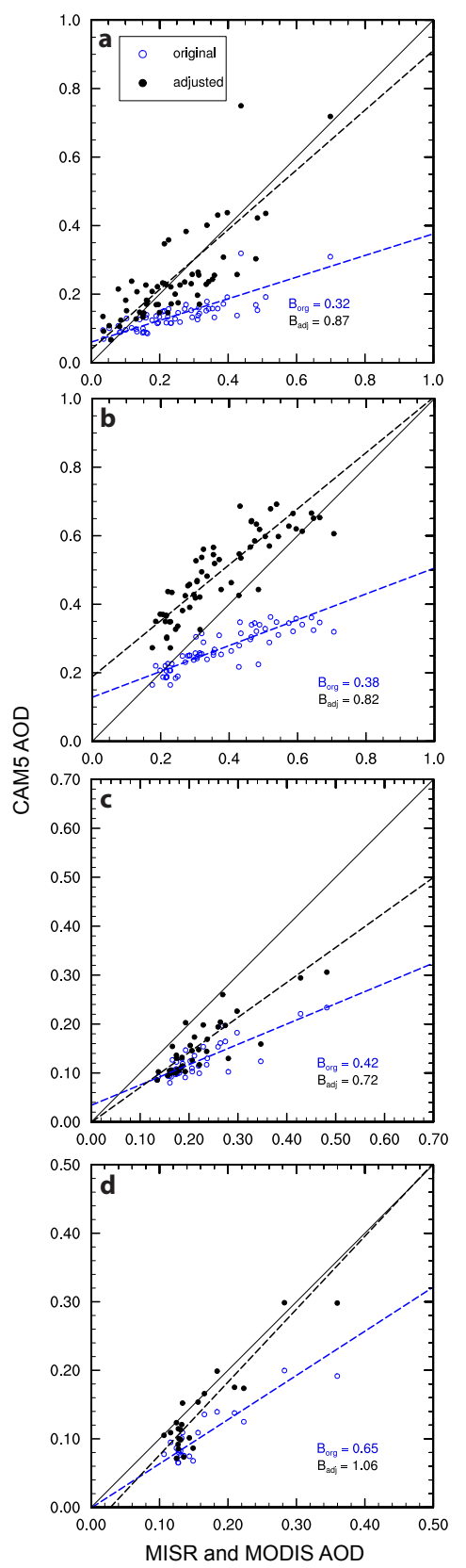

Fig. 2. Linear relations between CAM5-simulated aerosol optical depths (y-axis) and MISR-MODIS optical depths ( $\mathrm{x}$-axis) for unadjusted case (blue dots/line) and adjusted case (black dots/line) emissions cases. Regression slopes for the original emissions ( $B_{\text {orig. }}$ ) and adjusted emissions $\left(B_{\text {adj. }}\right)$ model simulations are shown in each panel. The three regions shown are (a) South America (SAM; $\left.25^{\circ} \mathrm{S}: 0,40: 65^{\circ} \mathrm{W}\right)$, (b) southern Africa (SAF; 15:5 $\left.\mathrm{S}, 10: 30^{\circ} \mathrm{E}\right)$ (c) Equatorial Asia (EAS; $\left.10^{\circ} \mathrm{S}: 7^{\circ} \mathrm{N}, 90: 150^{\circ} \mathrm{E}\right)$, and (d) boreal North America $\left(\mathrm{BNA} ; 50^{\circ} \mathrm{N}: 70^{\circ} \mathrm{N}, 170: 90^{\circ} \mathrm{W}\right)$. Only those months that cumulatively contributed $80 \%$ of regional emissions from 1997-2009 were included in the analysis. Correlation coefficients $\left(r^{2}\right)$ were 0.65 (unadj.) and 0.62 (adj.) for SAM; 0.72 (unadj.), 0.55 (adj.) for SAF; 0.69 (unadj.) and 0.71 (adj.) for EAS; and 0.78 (unadj.) and 0.83 (adj.) for BNA. fire emissions (Table 1). Each region's mean scaling factor was the average of scalars derived separately for MISR and MODIS observations. In other regions, where contributions from other aerosol sources were proportionally larger, it was not possible to use this optimization approach. In these regions we assigned scale factors based on ecosystem similarity and proximity. The scalars for SAM, SAF, EAS and BNA were 2.40, 2.10, 1.67 and 1.45, respectively, and were applied to biogeographically similar regions, as shown in Table 2 . In a second simulation we increased emissions by these scalars, preserving the same spatial and temporal distributions. Global smoke (the sum of $\mathrm{BC}$ and $\mathrm{OC}$ ) emissions from landscape fires increased from $40.6 \mathrm{Tg} \mathrm{yr}^{-1}$ to $79.9 \mathrm{Tg} \mathrm{yr}^{-1}$ as a result of the adjustment process. Total $\mathrm{SO}_{2}$ emissions were adjusted upward from 2.4 to $4.7 \mathrm{Tg} \mathrm{yr}^{-1}$. These adjustments were broadly similar to estimates from Johnston et al. (2012) who applied similar scaling techniques using the global GEOS-Chem model to study aerosol effects on human health. Time series biases, root mean squared errors and linear correlations (slopes) for each region showed considerable improvement between the original and adjusted cases (Fig. S3).

The second simulation, using adjusted emissions, produced linear fits between modeled and satellite-observed AODs that had slopes closer to 1.0 (ranging from 0.72 to 1.06 for SAM, SAF, EAS and BNA; Fig. 2). We evaluated our adjustments using AOD data from 21 individual AERONET stations across the tropics (Fig. 1). This confirmed our initial assumption that the relation between AODs and emissions was mostly linear. We compared CAM5 simulated optical depth to observations for only those months when greater than $30 \%$ of the optical depth from CAM5 was derived from fire. Even after considering the large spatial-scale mismatches between the model and the observations, our analysis revealed significant improvement in the linear relation between modeled and observed optical depths for individual stations in SAM, SAF and EAS (Fig. 3). Despite general improvement between the original and adjusted cases, lowbiases still persisted in eastern Africa and parts of equatorial Asia. This suggests the climate impacts we describe in the following sections are likely to be conservative. Table 3 summarizes the AOD improvements for the simulations we obtained after optimization.

\subsection{Effects of fire aerosols on climate using CESM}

We used the same configuration of CAM5-SOM (described in Sect. 2.1) to investigate the simulated climate response to fire aerosol forcing. We conducted two simulations: one with no prescribed surface fire aerosol emissions (NOFIRE), but aerosols emissions from all other sources, and one with surface fire aerosol emissions (FIRE) in addition to all other aerosol sources. Emissions for most species were compiled and adapted from various sources into a comprehensive dataset described by Lamarque et al. (2010). More 
Table 1. Summary of scaling factors for selected biomass burning regions.

\begin{tabular}{|c|c|c|c|c|}
\hline & \multicolumn{4}{|c|}{ Region } \\
\hline & South America ${ }^{1}$ & southern Africa ${ }^{2}$ & equatorial $\mathrm{Asia}^{3}$ & boreal North America ${ }^{4}$ \\
\hline Original sum of $\mathrm{BC}$ and $\mathrm{OC}$ emissions ${ }^{5}\left(\mathrm{Tg} \mathrm{yr}^{-1}\right)$ & 3.5 & 4.8 & 3.3 & 1.6 \\
\hline $\begin{array}{l}\text { Number of months contributing to } 80 \% \text { of emissions } \\
\text { (out of 156) }\end{array}$ & 29 & 31 & 18 & 11 \\
\hline MODIS scalar & 3.03 & 2.56 & 1.75 & 1.87 \\
\hline MODIS correlation $\left(r^{2}\right)$ & 0.71 & 0.78 & 0.67 & 0.88 \\
\hline MISR scalar & 1.77 & 1.63 & 1.59 & 1.02 \\
\hline MISR correlation $\left(r^{2}\right)$ & 0.71 & 0.73 & 0.71 & 0.84 \\
\hline AVERAGE (MISR and MODIS) scalar & 2.40 & 2.10 & 1.67 & 1.45 \\
\hline Adjusted sum of $\mathrm{BC}$ and $\mathrm{OC}$ emissions $\left(\mathrm{Tg} \mathrm{yr}^{-1}\right)$ & 8.5 & 10.0 & 5.6 & 2.3 \\
\hline
\end{tabular}

${ }^{1}$ South America (SAM), region bounded by $25^{\circ} \mathrm{S}-0,65-40^{\circ} \mathrm{W} .{ }^{2}$ Southern Africa (SAF), region bounded by $15-5^{\circ} \mathrm{S}, 10-30^{\circ} \mathrm{E}$.

${ }^{3}$ Equatorial Asia (EAS), region bounded by $10^{\circ} \mathrm{S}-7^{\circ} \mathrm{N}, 90-150^{\circ} \mathrm{E}$.

${ }^{4}$ Boreal North America (BNA), region bounded by $50-70^{\circ} \mathrm{N}, 170-90^{\circ} \mathrm{W}$.

${ }^{5}$ The original BC and OC emissions were $2 \times$ GFEDv 3 (van der Werf et al., 2010).

Table 2. Global BC and OC scalars and emissions from satellite-based optimization.

\begin{tabular}{|c|c|c|c|}
\hline GFED Region* & Aerosol emissions scalar & $\begin{array}{r}\text { Sum of OC and BC } \\
\text { emissions from } 2 \times \text { GFEDv3 } \\
\left(\mathrm{Tg} \mathrm{yr}^{-1}\right)\end{array}$ & $\begin{array}{r}\text { Adjusted sum of } \mathrm{OC} \\
\text { and } \mathrm{BC} \text { emissions } \\
\left(\mathrm{Tg} \mathrm{yr}^{-1}\right)\end{array}$ \\
\hline SHSA & 2.40 & 5.3 & 12.8 \\
\hline NHSA & same as SHSA & 0.4 & 1.0 \\
\hline CEAM & same as SHSA & 0.4 & 1.1 \\
\hline SHAF & 2.10 & 10.3 & 21.6 \\
\hline NHAF & same as SHAF & 8.3 & 17.4 \\
\hline EURO & same as SHAF & 0.09 & 0.21 \\
\hline AUST & same as SHAF & 2.4 & 5.0 \\
\hline EQAS & 1.67 & 3.6 & 6.1 \\
\hline SEAS & same as EQAS & 2.1 & 3.5 \\
\hline CEAS & same as EQAS & 0.7 & 1.3 \\
\hline MIDE & same as EQAS & 0.03 & 0.05 \\
\hline BONA & 1.45 & 2.1 & 3.0 \\
\hline BOAS & same as BONA & 4.5 & 6.5 \\
\hline TENA & same as BONA & 0.3 & 0.4 \\
\hline global total & 1.97 & 40.6 & 79.9 \\
\hline
\end{tabular}

specifically, surface emissions of trace gases and aerosols from industrial and natural non-fire sources were based on MOZART-4 emissions described in Emmons et al. (2010). For most species, anthropogenic emissions were from the POET inventory (Granier et al., 2005), except in Asia where emissions from the REAS inventory were substituted (Ohara et al., 2007). Fire emissions of $\mathrm{BC}, \mathrm{OC}$ and $\mathrm{SO}_{2}$ were obtained following the approach described in Sect. 2.2 (above). Fire emissions of other minor aerosols and trace gases were prescribed directly from GFEDv3. The standard configuration of the Community Land Model (CLM) automatically quantifies the radiative forcing associated with black carbon deposition on snow, which proves consequential to the high latitude climate response.

Each simulation began after a $15 \mathrm{yr}$ spin-up period and lasted for $52 \mathrm{yr}$. For the FIRE case we forced the model with four cycles of the adjusted 1997-2009 emissions described above. As a result, the FIRE simulation included observed year-to-year variability in emissions during each cycle. The NOFIRE simulation was identical to the FIRE simulation but did not include fire emissions of $\mathrm{OC}, \mathrm{BC}$ or $\mathrm{SO}_{2}$. The use of $52 \mathrm{yr}$ simulations allowed us to quantify fire-induced climate 
Table 3. Comparison of optical depths from simulations with original and adjusted GFEDv3 emissions.

\begin{tabular}{|c|c|c|c|c|c|}
\hline \multirow[t]{2}{*}{ Region } & & \multirow[t]{2}{*}{ Observed } & \multicolumn{2}{|c|}{ Modeled } & \multirow{2}{*}{$\begin{array}{c}\text { Percent }(\%) \\
\text { change }\end{array}$} \\
\hline & & & (original emissions) & (adjusted emissions) & \\
\hline \multirow{3}{*}{ South America (SAM) } & MISR & 0.141 & 0.121 & 0.152 & 26 \\
\hline & MODIS & 0.140 & 0.124 & 0.158 & 27 \\
\hline & AERONET* & 0.301 & 0.112 & 0.259 & 129 \\
\hline \multirow{3}{*}{ southern Africa (SAF) } & MISR & 0.258 & 0.189 & 0.289 & 53 \\
\hline & MODIS & 0.278 & 0.186 & 0.287 & 54 \\
\hline & AERONET & 0.253 & 0.124 & 0.207 & 71 \\
\hline \multirow{3}{*}{ equatorial Asia (EAS) } & MISR & 0.160 & 0.089 & 0.090 & 1 \\
\hline & MODIS & 0.155 & 0.093 & 0.095 & 2 \\
\hline & AERONET & 0.190 & 0.109 & 0.151 & 47 \\
\hline \multirow{3}{*}{ boreal North America (BNA) } & MISR & 0.124 & 0.051 & 0.055 & 8 \\
\hline & MODIS & 0.136 & 0.058 & 0.062 & 7 \\
\hline & AERONET & - & - & - & - \\
\hline
\end{tabular}

* AERONET optical depths are only those where greater than $30 \%$ of the AOD simulated by CAM5 is from fire.

Regions are the same as those in Table 1.

responses in a statiscally robust way, given the internal climate variability within each simulation and also the large interannual variability of fire emissions that occurred in many regions.

\section{Results}

\subsection{Spatial and meridional climate response to fire aerosol emissions}

The presence of fire aerosols in the FIRE simulation produced a global, area-weighted AOD increase of $1.5 \times 10^{-2} \pm 0.2 \times 10^{-2}(10 \%)$ (Table 4), and large regional increases over the middle of central South America, Africa and equatorial Asia (Fig. 4). Remote swaths of open ocean also exhibited significant AOD increases (between 0.001 and 0.01 ), suggesting that the lifetimes of some fire aerosols were long enough to allow for long-range transport. In most cases, the maximum AOD increases occurred over regions of consistently high fire emissions. For example, over southern Africa $\left(15-5^{\circ} \mathrm{S} ; 10-30^{\circ} \mathrm{E}\right)$ and South America $\left(25^{\circ} \mathrm{S}-\right.$ $0 ; 65-50^{\circ} \mathrm{E}$ ), fires increased annual mean AOD by an areaaveraged $0.19 \pm 0.03(199 \%)$ and $0.08 \pm 0.02(91 \%)$, respectively. Zonally-averaged global AOD increases were at a maximum of 0.06 between $10^{\circ} \mathrm{S}$ and $10^{\circ} \mathrm{N}$, corresponding to consistently high fire emissions over Africa and South America, with another relative maximum between $50^{\circ} \mathrm{N}$ and $60^{\circ} \mathrm{N}$ over North American and Eurasian boreal forests (Fig. 5). Optical depth exhibited a clear seasonal cycle and reached a zonally-averaged maximum during DJF around $5^{\circ} \mathrm{N}(0.11)$ and during JJA at $5^{\circ} \mathrm{S}(0.10)$.

The total, top-of-atmosphere, direct radiative forcing from fire aerosols was $+0.18 \pm 0.10 \mathrm{~W} \mathrm{~m}^{-2}$ (Fig. 6a; Table 4). Regions of highest positive radiative forcing were generally in the tropical oceans, corresponding to high AODs, though directly over fire source regions (e.g., central Amazonia, boreal North America), radiative forcing was slightly negative. In response to the aerosol forcing, globally averaged all-sky net surface shortwave $\left(S_{\text {net }}\right)$ decreased by $1.3 \pm 0.2 \mathrm{~W} \mathrm{~m}^{-2}$ (1\%; Fig. 6b; Table 4). Like AOD, the largest changes occurred near or downwind of the major tropical burning regions. Area-averaged decreases over southern Africa (for the same region defined above) and South America (for the same region defined above) were $-19.1 \pm 3.2 \mathrm{~W} \mathrm{~m}^{-2}$ $(8 \%)$ and $-9.1 \pm 1.8 \mathrm{~W} \mathrm{~m}^{-2}(4 \%)$, respectively, with negative anomalies up to $-30 \mathrm{~W} \mathrm{~m}^{-2}$ over some regions within southern Africa. The zonally averaged pattern of $S_{n e t}$ anomalies closely followed AOD, with the maximum reduction $\left(-5 \mathrm{~W} \mathrm{~m}^{-2}\right)$ occurring just south of the Equator (Fig. 5).

The combination of increased AOD and reduced surface shortwave radiation reduced surface temperature in most areas $\left(0.13 \pm 0.01{ }^{\circ} \mathrm{C}\right.$, Table 4 , Fig. $\left.6 c\right)$. Outside of the intertropical convergence zone (ITCZ) in the eastern Pacific and the high-latitude storm tracks, the largest reductions in temperature occurred over the continents. In southern Africa (same region as above), average temperature decreased by $0.46 \pm 0.07^{\circ} \mathrm{C}$, and over the southern Amazon (same region as above) by $0.37 \pm 0.07^{\circ} \mathrm{C}$. Global temperature anomalies were at a zonally-averaged minimum at the Equator and northward $\left(-0.2^{\circ} \mathrm{C}\right)$ but large reductions also occurred near the South Pole. Temperature decreases near the Equator and $60^{\circ} \mathrm{N}$ corresponded to a relatively small zonal AOD maximum, suggesting that direct forcing from aerosols at higher latitudes had a proportionately greater impact. However, the lack of a significant spatial correlation between temperature changes and $S_{\text {net }}$ anomalies suggests that direct effects from smoke on the local atmosphere and surface radiation budget were not responsible for all of the meridional and global temperature response. 
Table 4. Summary of the simulated global climate response to fire aerosols.

\begin{tabular}{|c|c|c|c|}
\hline Earth System variable & NOFIRE (control) & FIRE-NOFIRE (C.I. ${ }^{\mathrm{a}}$ ) & $\%$ change \\
\hline \multicolumn{4}{|l|}{ Global } \\
\hline Aerosol optical depth & 0.15 & $+0.02(0.002)$ & +10 \\
\hline Top-of-atmosphere radiative forcing $\left(\mathrm{W} \mathrm{m}^{-2}\right)$ & -0.47 & $+0.18(0.10)$ & \\
\hline Net surface shortwave radiation $\left(\mathrm{W} \mathrm{m}^{-2}\right)$ & 155.3 & $-1.3(0.2)$ & -1 \\
\hline Surface air temperature $\left({ }^{\circ} \mathrm{C}\right)$ & 14.8 & $-0.13(0.01)$ & \\
\hline Precipitation $\left(\mathrm{mm} \mathrm{d}^{-1}\right)$ & 2.88 & $-0.03(0.003)$ & -1 \\
\hline Mean maximum annual NH $\psi\left(\times 10^{10} \mathrm{~kg} \mathrm{~s}^{-1}\right)^{b}$ & 8.8 & $-0.1(0.1)$ & -1 \\
\hline Mean maximum DJF NH $\psi\left(\times 10^{10} \mathrm{~kg} \mathrm{~s}^{-1}\right)$ & 23 & $-0.3(0.2)$ & -1 \\
\hline Width of NH Hadley Cell $\left(\Delta \phi^{\circ}\right)$ & 31.3 & $+0.4(0.4)$ & +1 \\
\hline \multicolumn{4}{|l|}{ South America $(\mathrm{SAM})^{\mathrm{c}}$} \\
\hline Aerosol optical depth & 0.09 & $+0.08(0.02)$ & +91 \\
\hline Net surface shortwave radiation $\left(\mathrm{W} \mathrm{m}^{-2}\right)$ & 215.7 & $-9.1(1.8)$ & -4 \\
\hline Surface air temperature $\left({ }^{\circ} \mathrm{C}\right)$ & 26.7 & $-0.37(0.07)$ & \\
\hline Precipitation $\left(\mathrm{mm} \mathrm{d}^{-1}\right)$ & 3.62 & $-0.08(0.05)$ & -2 \\
\hline \multicolumn{4}{|l|}{ southern Africa (SAF) } \\
\hline Aerosol optical depth & 0.10 & $+0.19(0.03)$ & +199 \\
\hline Net surface shortwave radiation $\left(\mathrm{W} \mathrm{m}^{-2}\right)$ & 243.2 & $-19.1(3.2)$ & -8 \\
\hline Surface air temperature $\left({ }^{\circ} \mathrm{C}\right)$ & 24.0 & $-0.46(0.07)$ & \\
\hline Precipitation $\left(\mathrm{mm} \mathrm{d}^{-1}\right)$ & 3.32 & $-0.24(0.05)$ & -7 \\
\hline
\end{tabular}

On average, global precipitation decreased $2.9 \times 10^{-2} \pm$ $0.3 \times 10^{-2} \mathrm{~mm} \mathrm{~d}^{-1}(1 \%)$ (Table 4), but anomalies showed a complex spatial pattern of large precipitation decreases at the Equator, slightly smaller decreases in the Northern Hemisphere storm track and increases between 5 and $10^{\circ} \mathrm{N}$ (and between 5 and $10^{\circ} \mathrm{S}$ ). Over the main burning regions of Africa and South America, precipitation decreased $2.4 \times 10^{-1} \pm 0.5 \times 10^{-1} \mathrm{~mm} \mathrm{~d}^{-1}(7 \%)$ and $0.8 \times 10^{-1} \pm$ $0.5 \times 10^{-1} \mathrm{~mm} \mathrm{~d}^{-1}(2 \%)$, respectively. Some of this precipitation decrease appeared to have been caused by local aerosol effects on surface convergence, upward vertical wind speeds $(\omega)$ and atmospheric warming and its effect on the lapse rate. For example, the temperature difference over Africa (same region as above) between $700 \mathrm{mb}$ and the surface decreased by $0.43 \pm 0.10^{\circ} \mathrm{C}$, reflecting increased atmospheric stability and occurring simultaneously with a decrease in upward wind velocity of $9.1 \times 10^{-4} \pm 12.7 \times 10^{-4} \mathrm{~Pa} \mathrm{~s}^{-1}$ at $500 \mathrm{mb}$ (Fig. S4). It is likely, however, that other mechanisms are needed to explain the macroscale change in global precipitation, including changes in the remote Pacific shown in Fig. 4d.

\subsection{Fire aerosol effects on the Hadley circulation}

We used meridional wind velocities and surface pressure to compute the annual mean mass streamfunction (described by Oort and Yienger, 1996) for ERA-interim data and our CAM5 simulations (Fig. 7a, b). Two Hadley cells, between $30^{\circ} \mathrm{S}$ and $30^{\circ} \mathrm{N}$, were visible in both the ERA-interim data as well as the CAM5 simulations. The model adequately matched the placement and strength of the two cells when compared to the reanalysis. The simulated and observed streamfunctions $(\psi)$ placed the dividing line between the southern and northern Hadley cells just north of the Equator, corresponding to the latitude of mean ascent and near-permanent residence of the ITCZ at $5^{\circ} \mathrm{N}$. ERAinterim data indicated a slightly stronger southern Hadley cell with maximum $\psi$ values exceeding $-11 \times 10^{10} \mathrm{~kg} \mathrm{~s}^{-1}$, compared to $-8.5 \times 10^{10} \mathrm{~kg} \mathrm{~s}^{-1}$ for CAM5. However, maximum $\psi$ values for the northern cell were similar between model and data: $8.1 \times 10^{10} \mathrm{~kg} \mathrm{~s}^{-1}$ vs. $8.8 \times 10^{10} \mathrm{~kg} \mathrm{~s}^{-1}$, respectively. Vertical velocity $(\omega)$ fields from ERA-interim data and CAM5 simulations showed the region of maximum ascent (negative $\omega$ values) between $10^{\circ} \mathrm{S}$ and $10^{\circ} \mathrm{N}$, roughly corresponding to the division between the northern and southern Hadley cells (Fig. 8a, b). Upward velocities near $2 \times 10^{-2} \mathrm{~m} \mathrm{~s}^{-1}$ characterized the ascending branches of the Hadley cells.

Presence of fire aerosols at the Equator in the FIRE simulation weakened both the northern and southern Hadley cells (Fig. 7c, d). The southern Hadley cell increased by as much as $3.0 \times 10^{9} \mathrm{~kg} \mathrm{~s}^{-1}$ around $5^{\circ} \mathrm{S}$, representing a net reduction 

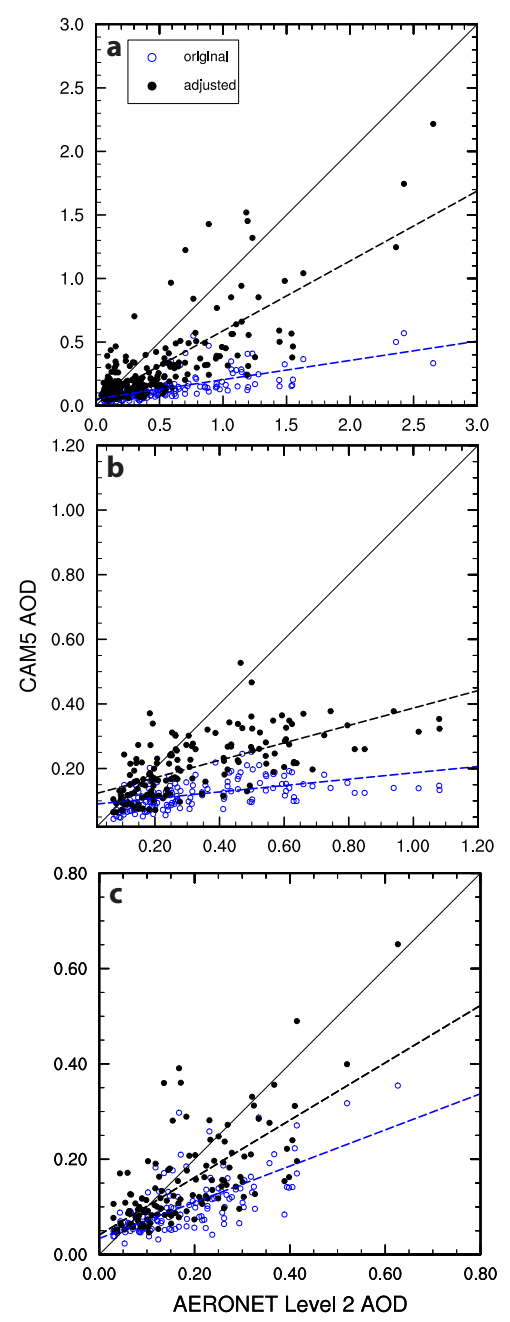

Fig. 3. Linear relations between CAM5 simulated aerosol optical depths (y-axis) and AERONET optical depths (x-axis) for the unadjusted case (blue dots/line) and adjusted case (black dots/line), showing better agreement in the adjusted scenario. Regions are the same as Fig. 2: (a) South America (SAM), (b) southern Africa (SAF) and (c) equatorial Asia (EA). Only those months where CAM5 AOD from fire emissions was greater than or equal to $30 \%$ were used in our comparisons.

in southward transport of around $10 \%$, though reductions were smaller further south in the region of maximum absolute $\psi$. Similarly, $\psi$ values in the northern Hadley cell decreased by $-3.8 \times 10^{9} \mathrm{~kg} \mathrm{~s}^{-1}$ at $5^{\circ} \mathrm{N}$, also an approximate $10 \%$ reduction in northward transport. The maximum $\psi$ for DJF decreased from $2.30 \times 10^{11}$ to $2.27 \times 10^{11} \mathrm{~kg} \mathrm{~s}^{-1}$ (a reduction of $0.3 \pm 0.2 \times 10^{10} \mathrm{~kg} \mathrm{~s}^{-1}$ ), though reductions in excess of $6.7 \times 10^{9} \mathrm{~kg} \mathrm{~s}^{-1}$ occurred closer to the Equator. Despite Hadley cell weakening, the width of the tropics increased slightly. We calculated the annually averaged northward extent of the Hadley cell for each simulation as the latitude $(\phi)$ at which $\psi$ (at $500 \mathrm{mb}$ ) switched from positive to negative, as described in Allen et al. (2012a). We found that

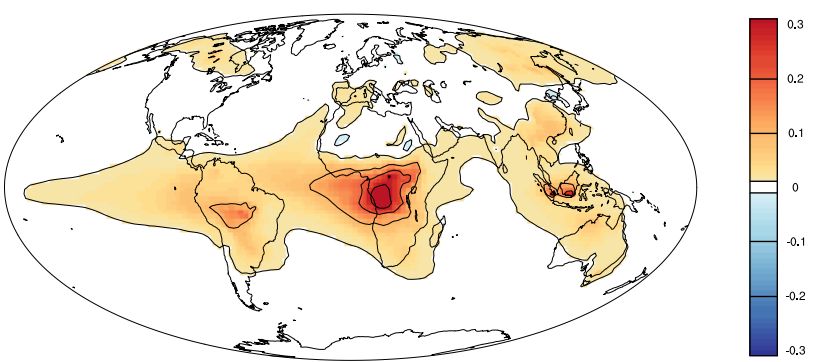

Fig. 4. Global map of aerosol optical depth anomalies (FIRE minus NOFIRE) from the CAM5 simulations. Averages were calculated using all $52 \mathrm{yr}$ from each simulation (and excluding the preceding spin-up periods). This applies to all remaining figures and tables.

$\Delta \phi$ between the FIRE and NOFIRE cases was $0.4 \pm 0.4^{\circ}$ suggesting that the tropics widened.

Weakening of the Hadley circulation was likely a result of the aerosol forcing between $10^{\circ} \mathrm{S}$ and $10^{\circ} \mathrm{N}$ (e.g., Fig. 7d). Elevated fire aerosols in this latitude band both cooled the surface and warmed the atmosphere. In some places, local aerosol-induced subsidence (more positive values of $\omega$ ) contributed to the reduction in $\psi$ values near the Equator. For example, during the Northern Hemisphere summer (MayOctober), high AODs over southern Africa contributed to a column heating of greater than $0.9 \mathrm{~K} \mathrm{~d}^{-1}$ from $1000-700 \mathrm{mb}$ and local maximum temperature increase of $0.4^{\circ} \mathrm{C}$ at $700 \mathrm{mb}$, both of which increased $\omega$ by $4 \times 10^{-2} \mathrm{~Pa} \mathrm{~s}^{-1}$ near $850 \mathrm{mb}$ and limited the amount of equatorial convection (Fig. S5). This caused a local weakening of the poleward transport of mass in the southern Hadley cell.

Similarly, the global reduction in upward vertical velocities near the Equator (and subsequent weakening of $\psi$, Fig. 8c) appeared to be linked with sharp reductions in SST and mid-tropospheric heating in a narrow swath between $5^{\circ} \mathrm{S}$ and $5^{\circ} \mathrm{N}$. In particular, over much of the Pacific the largest $\omega$ increases were co-located with reductions in SSTs, suggesting that the fire-induced temperature decreases had the largest effect on $\omega$ in regions of maximum convection. Pronounced heating between 1000 and $500 \mathrm{mb}$ suggested that the long-range transport of aerosols over the Pacific contributed to the suppression of convection. Sharp decreases in atmospheric heating rates at altitudes above $500 \mathrm{mb}$ corroborate a reduction in mid- to upper-level condensation. Over the tropical Pacific $\left(180-90^{\circ} \mathrm{W}\right), \omega$ anomalies exceeded $2.0 \times 10^{-5} \mathrm{Pas}^{-1}$ in response to SST reductions greater than $0.3^{\circ} \mathrm{C}$ and maximum heating rates of $0.1 \mathrm{~K}$ $\mathrm{d}^{-1}$ at $850 \mathrm{mb}$ (Fig. S6).

\section{Discussion}

Simulated fire aerosols reduced net surface shortwave radiation, especially over the major burning regions of South America, Africa and equatorial Asia, and increased 


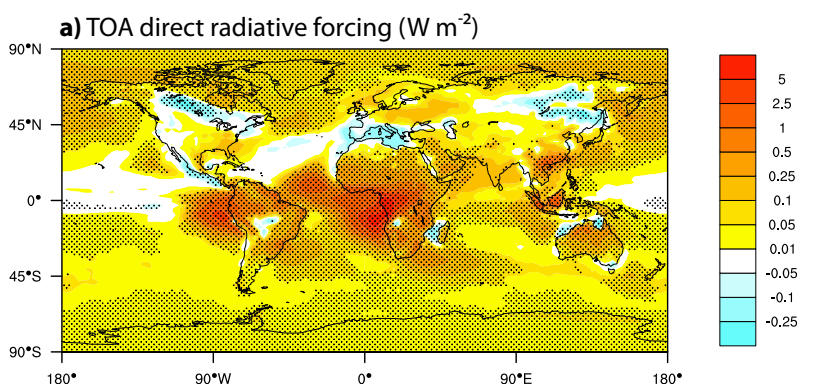

b) Net surface SW radiation $\left(\mathrm{W} \mathrm{m}^{2}\right)$
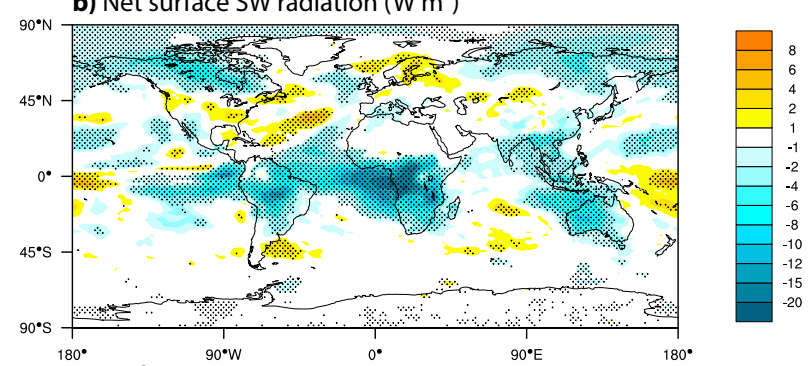

c) Surface air temperature $\left({ }^{\circ} \mathrm{C}\right)$
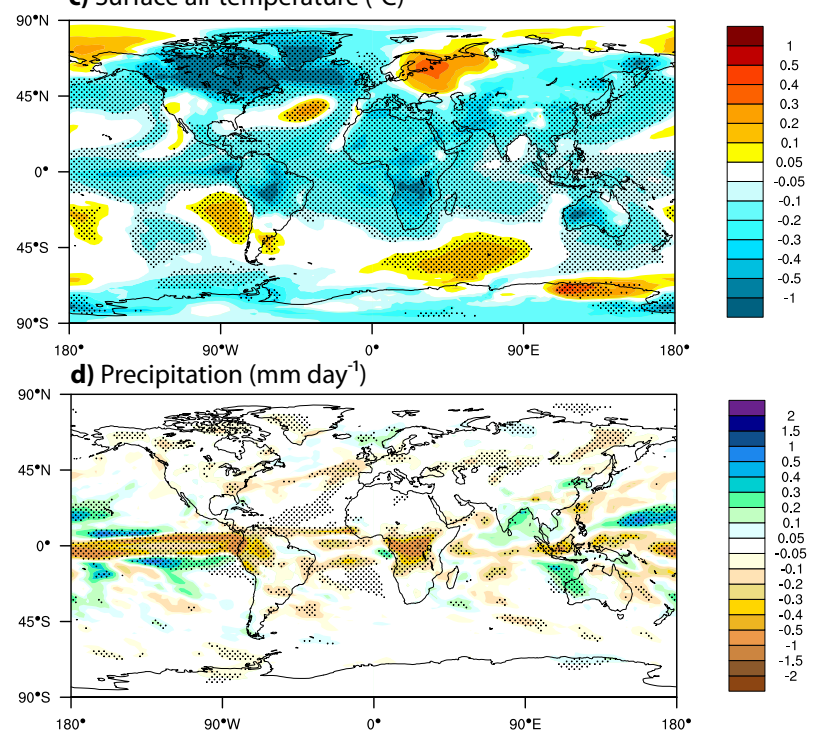

Fig. 5. Zonally averaged climate anomalies (FIRE - NOFIRE) from CAM5 simulations: (a) aerosol optical depth, (b) net insolation $\left(\mathrm{W} \mathrm{m}^{-2}\right)$, (c) temperature $\left({ }^{\circ} \mathrm{C}\right)$, and (d) precipitation (percent $(\%)$ change). Thin lines are seasonal averages, thick lines are annual averages.

atmospheric warming, especially in the tropics and midlatitudes. Global surface air temperatures were lower and in some places negative anomalies exceeded $-0.5^{\circ} \mathrm{C}$. Though changes in surface radiation were largely confined to high biomass burning regions, the temperature response was more globally distributed. This was likely due to a substantial reduction in heat transport from the tropics to mid- and highlatitude regions. The surface temperature reductions combined with increased tropospheric heating near the Equator reduced convection in the ascending branches of the two

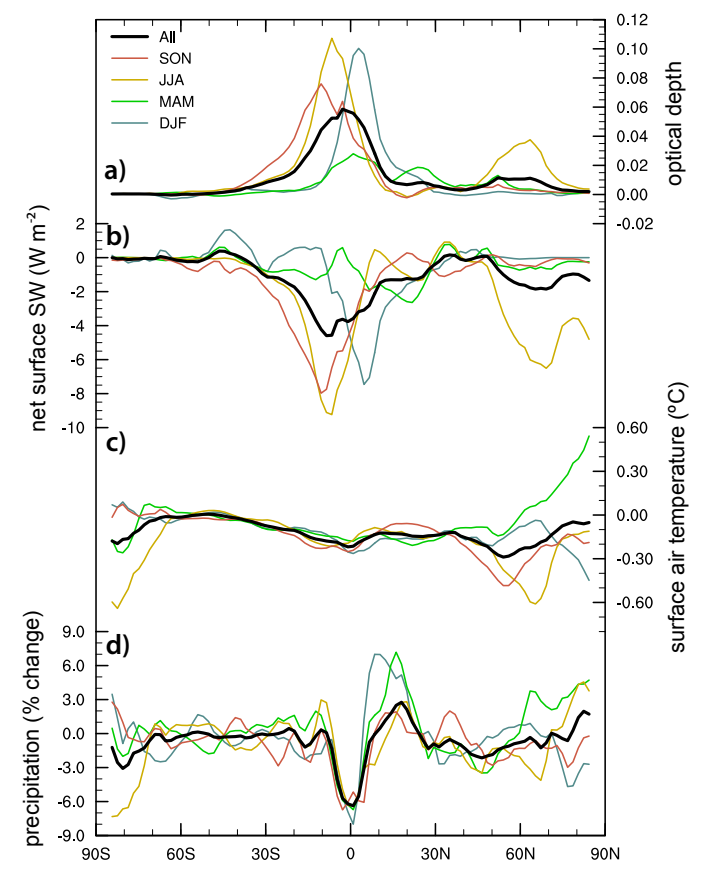

Fig. 6. Global maps of climate anomalies (FIRE minus NOFIRE for (b-d) only) from CAM5 simulations: (a) top-of-atmosphere radiative forcing ( $\mathrm{W} \mathrm{m}^{-2}$ from FIRE run only), (b) net insolation $\left(\mathrm{W} \mathrm{m}^{-2}\right)$, (c) surface air temperature $\left({ }^{\circ} \mathrm{C}\right)$, and (d) precipitation $\left(\mathrm{mm} \mathrm{d}^{-1}\right)$. Dotted stippling of statistical significance $(95 \%)$. Significance was determined by computing the $t$ test statistic at each grid cell for $\alpha=0.05$. Surface air temperature was the mean midlayer air temperature in the lowest atmospheric level of the model.

Hadley cells. These results are consistent with conclusions from Tosca et al. (2010) which showed a link between fire emissions and precipitation reductions in equatorial Asia. In sum, the presence of fire aerosols in the troposphere caused a small general weakening of the northern and southern Hadley cells in simulations with CAM5.

The mechanisms for Hadley cell weakening are also largely consistent with results from Quan et al. (2005) that link SSTs to the strength of the Hadley circulation. They suggest that from 1950 to present, increased surface temperatures have contributed to a gradual strengthening of the Hadley circulation. They also note that the strength of the Hadley circulation is positively correlated with El Niño (warm SST) events in the eastern Pacific (and negatively correlated with La Niña (cold SST) events). Mitas and Clement (2005) and Lu et al. (2007) also present evidence that surface warming is positively correlated with Hadley cell strength.

The latter study found a $50.4 \times 10^{8} \mathrm{~kg} \mathrm{~s}^{-1}$ increase in the maximum DJF Northern Hemisphere mass streamfunction during 1979-2003, a period when surface temperatures increased by $0.6^{\circ} \mathrm{C}$ (Hansen et al., 2010). Given a mean value of $8.8 \times 10^{10} \mathrm{~kg} \mathrm{~s}^{-1}$, this corresponds to a cumulative increase of $5.7 \%$. Although decadal changes in fire emissions 


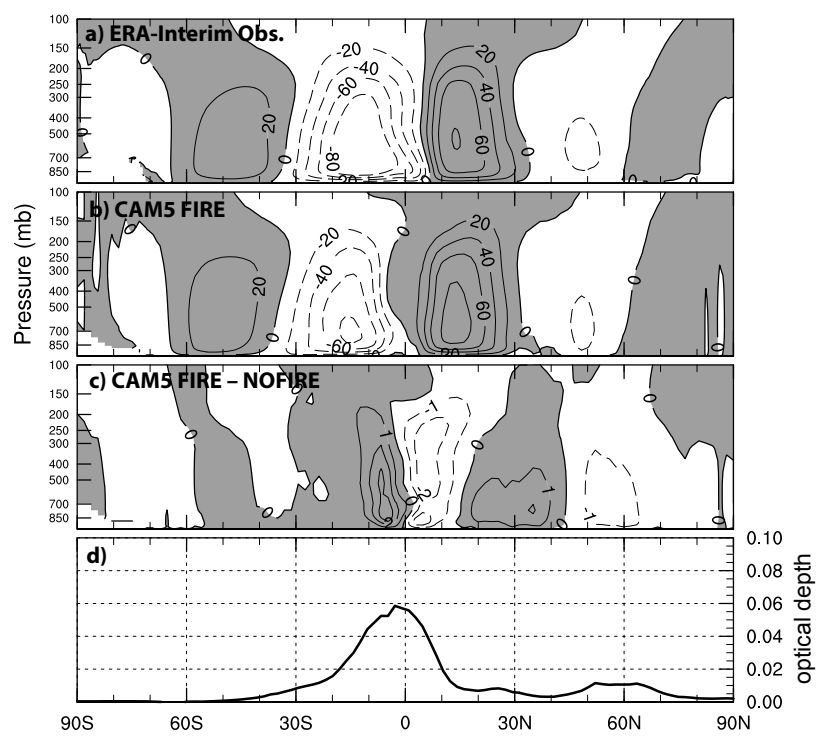

Fig. 7. Zonal-mean (annual) mass streamfunction $(\psi)$ derived from (a) ECMWF ERA-interim observations, (b) CAM5 simulations including fire aerosols, and (c) the difference between the FIRE and NOFIRE simulations. Units are in $10^{9} \mathrm{~kg} \mathrm{~s}^{-1}$ for all plots. Contour intervals vary. Shaded regions indicate northward transport, unshaded regions are southward transport. (d) is the zonally-averaged AOD.

are not well understood, it is likely that deforestation and savanna woodland fires have increased significantly since 1950. For illustrative purposes, if we assume fires increased by approximately $50 \%$ over this time, then, using a preliminary analysis of output from our simulations, fires may have offset Hadley strengthening during this interval by $4 \times 10^{8} \mathrm{~kg} \mathrm{~s}^{-1}$. Thus, in the absence of possible changes in the fire regime, the strengthening of the Hadley circulation could have been approximately $8 \%$ greater.

Analysis of reanalysis observations suggests that the width of the Northern Hemisphere Hadley circulation has increased in recent decades, by $0.3^{\circ}$ decade during 1979-1999 (Allen et al., 2012a). Though we simulate a decrease in Hadley cell strength, we also show a significant widening of the annual northern Hadley cell $\left(\Delta \phi=0.4 \pm 0.4^{\circ}\right)$, in the same direction as the observations. This is consistent with results from Allen et al. (2012b) who showed that recent observations of Hadley cell expansion can be partly attributed to mid-latitude tropospheric heating from black carbon aerosols. Using various measures for determining tropical width, their simulations attribute an increase of $0.3-1.0^{\circ}$ decade $^{-1}$ for 1979-2009 from mid-latitude BC warming of the lower troposphere. Surface air warming from greenhouse gas forcing is known to partially explain recent increases in Hadley cell strength, but a stronger Hadley circulation usually results in an equatorward contraction (Lu et al., 2008). However, black carbon heating increases atmospheric stability, which pushes the baroclinic zone poleward, resulting in an expansion of the Hadley

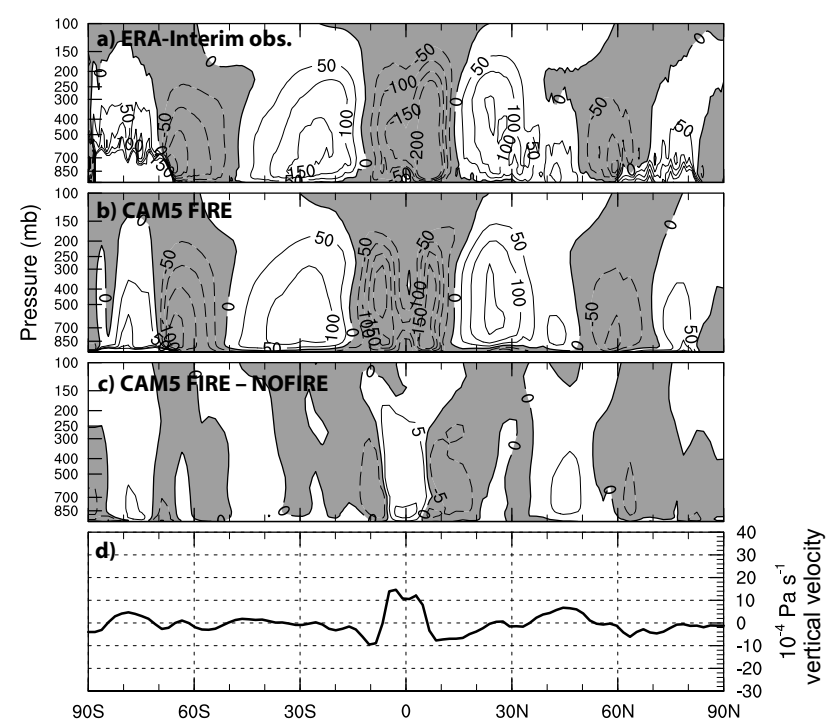

Fig. 8. Zonal-mean (annual) vertical velocities $(\omega)$ derived from (a) ECMWF ERA-interim observations, (b) CAM5 simulations including fire aerosols, and (c) the difference between the FIRE and NOFIRE simulations. Units are in $10^{-4} \mathrm{~Pa} \mathrm{~s}^{-1}$ for all plots. Contour intervals vary. Negative values (shaded regions) indicate upward velocities, positive values (un-shaded regions) are downward velocities. (d) is the $500 \mathrm{mb}$ vertical velocity anomalies (as in c).

cell. Following the same fire scenario as in the previous paragraph, our CESM simulations suggest fires may have contributed to approximately $10 \%$ of the observed trend.

Given that we scaled fire emissions to match simulated AODs to observations in burning regions, it is likely that our simulations adequately but conservatively captured the magnitude of the direct forcing from fire aerosols. For example, we estimated that fires increased AOD by approximately 0.02 , which is in line with estimates of 0.02-0.03 from Mahowald et al. (2011) and 0.03 from Bauer and Menon (2012). This represents a $10 \%$ increase over the global background aerosol load. We also acknowledge that scaling surface emissions so that simulated AODs match observations is not a seamless fix to the underestimation of AOD within CAM5, and that other factors, such as secondary aerosol formation and wet deposition processes (Xian et al., 2009), may contribute to discrepancies between simulations and observations.

Our results demonstrate a plausible link between smoke aerosols and changes in global circulation but do not address whether simulated circulation changes have any impact on fire distribution or occurrence. Elevated AODs generally reduced surface temperatures, especially those in the tropical Pacific where our simulations showed a La Niña-like response to the smoke forcing. The combination of decreased temperatures, atmospheric heating and aerosol-cloud indirect effects reduced convection at the Equator and weakened the Hadley circulation. Over some locales, like the tropical 
forests of Africa and South America, simulated reductions in precipitation (between 5 and 15\%) lowered soil moisture content in the top several layers, which increased drought stress. This would make it easier for land managers to use fire as a tool in clearing land for pastures, croplands or plantations. Combined with the modeled relationship between global warming and tropical drying (Neelin et al., 2006), the increased drought stress may enhance positive feedbacks between fire and climate. However, some of these ecosystem impacts are likely offset or modified by the strengthening of the Hadley cells in response to global warming.

Owing to the coarse resolution of CAM5 and the complicated relationship between cloud microphysics and aerosols, it is intrinsically difficult to simulate the mesoscale meteorological response to smoke. In regions like equatorial Asia, geography and complicated sea-breeze interactions make it difficult to model convection, and thus difficult to fully realize the climate response to smoke-aerosol forcing. We note the difficulty in accurately representing spatial and temporal patterns of precipitation and circulation changes. This study, therefore, is a first estimate of the global climate response to fire emissions from CAM5 that accounts for direct and semidirect aerosol effects.

\section{Conclusions}

We used a global climate model to simulate the sensitivity of the climate to fire aerosols. We first optimized black and organic carbon emissions by matching simulated and observed optical depths. Validation of modeled AODs with surfacebased measurements showed that our emissions yielded more realistic distributions of aerosols after our scaling approach. Global simulations that included fire emissions produced elevated AODs, especially across the tropics. In response to the aerosol forcing, global temperatures declined with maximum reductions in the tropics. Changes in precipitation patterns suggest that fire-emitted aerosols modify global circulation through a combination of decreased surface insolation, atmospheric heating, reduced surface temperature and increased subsidence globally and in tropical convective regions. Our results suggest a link between fire aerosols and the strength and extent of the Hadley circulation.

Important next steps include assessing the regional impact of fire aerosols, inclusion of indirect effects in modeling studies and determining the relative importance of the direct and indirect aerosol contributions to the climate response. Assessing which regions contribute the most to the large response in the eastern Pacific could be done by isolating emissions from Africa, South America and other high burning regions in individual simulations. Furthermore, the Modal Aerosol Model (MAM) has been developed and embedded in the latest version of CAM5 and simulates aerosol indirect effects in stratus clouds (Liu et al., 2012). One important direction for future research is to isolate the individ- ual contributions from the direct and indirect aerosol effects, using MAM embedded within CAM5. A final important next step is understanding the combined effects of fire-induced changes in solar radiation, precipitation, albedo and deposition on tropical ecosystem function.

\section{Supplementary material related to this article is available online at: http://www.atmos-chem-phys.net/13/ 5227/2013/acp-13-5227-2013-supplement.pdf.}

Acknowledgements. We are grateful for support from NSF (AGS-1048890) and NASA (NNX11AF96G). M.G.T. received support from a NASA Earth and Space Science Fellowship (NNX08AU90H). C.S.Z. acknowledges NSF (ARC-0714088) and NASA (NNX07AR23G) support.

Edited by: Y. Balkanski

\section{References}

Ackerman, A. S., Toon, O. B., Stevens, D. E., Heymsfield, A. J., Ramanathan, V., and Welton, E. J.: Reduction of tropical cloudiness by soot, Science, 288, 1042-1047, doi:10.1126/science.288.5468.1042, 2000.

Akagi, S. K., Yokelson, R. J., Wiedinmyer, C., Alvarado, M. J., Reid, J. S., Karl, T., Crounse, J. D., and Wennberg, P. O.: Emission factors for open and domestic biomass burning for use in atmospheric models, Atmos. Chem. Phys., 11, 4039-4072, doi:10.5194/acp-11-4039-2011, 2011.

Albrecht, B. A.: Aerosols, cloud microphysics, and fractional cloudiness, Science, 245, 1227-1230, 1989.

Allen, R. J., Sherwood, S. C., Norris, J. R., and Zender, C. S.: The equilibrium response to idealized thermal forcings in a comprehensive GCM: implications for recent tropical expansion, Atmos. Chem. Phys., 12, 4795-4816, doi:10.5194/acp-12-47952012, 2012a.

Allen, R. J., Sherwood, S. C., Norris, J. R., and Zender, C. S.: Recent Northern Hemisphere tropical expansion primarily driven by heterogeneous warming agents, Nature, 485, 350-354, 2012b.

Andreae, M. O. and Merlet, P.: Emission of trace gases and aerosols from biomass burning, Glob. Biogeochem. Cy., 15, 955-966, 2001.

Andreae, M. O. and Rosenfeld, D.: Aerosol cloud precipitation interactions. Part 1. The nature and sources of cloud-active aerosols, Earth Sci. Rev., 89, 13-41, 2008.

Andreae, M. O., Rosenfeld, D., Artaxo, P., Costa, A. A., Frank, G. P., Longo, K. M., and Silva-Dias, M. A. F.: Smoking rain clouds over the Amazon, Science, 303, 1337-1342, doi:10.1126/science.1092779, 2004.

Bauer, S. E. and Menon, S.: Aerosol direct, indirect, semidirect, and surface albedo effects from sector contributions based on the IPCC AR5 emissions for preindustrial and present-day conditions, J. Geophys. Res., 117, D01206, doi:10.1029/2011JD016816, 2012. 
Bowman, D. M. J. S., Balch, J. K., Ataxo, P., Bond, W. J., Carlson, J. M., Cochrane, M. A., D’Antonio, C. M., DeFries, R. S., Doyle, J. C., Harrison, S. P., Johnston, F. H., Keeley, J. E., Krawchuk, M. A., Kull, C. A., Marston, J. B., Moritz, M. A., Prentice, I. C., Roos, C. I., Scott, A. C., Swetnam, T. W., van der Werf, G. R., and Pyne, S. J.: Fire in the Earth System, Science, 324, 481-484, doi:10.1126/science.1163886, 2009.

Bretherton, C. S. and Park, S.: A new moist turbulence parametrization in the Community Atmosphere Model, J. Clim., 22, 3422$3448,2009$.

Chen, Y., Randerson, J. T., Morton, D. C., DeFries, R. S., Collatz, G. J., Kasibhatla, P. S., Giglio, L., Jin, Y., and Marlier, M. E.: Forecasting fire season severity in South America using sea surface temperature anomalies, Science, 334, 787-791, doi:10.1126/science.1209472, 2011.

Chylek, P. and Wong, J.: Effect of absorbing aerosols on global radiation budget, Geophys. Res. Lett., 8, 929-931, 1995.

Collins, W. D., Rasch, P. J., Boville, A., Hack, J. J., MaCaa, J. R., Williamson, D. L., Kiehl, J. T., Briegleb, B. P., Bitz, C., Lin, S. J., Zhang, M., and Dai, Y.: Description of the NCAR Community Atmosphere Model (CAM 3.0), Tech. rep., National Center for Atmospheric Research, 2004.

Crutzen, P. J., Heidt, L. E., Krasnec, J. P., Pollock, W. H., and Seiler, W.: Biomass burning as a source of atmospheric gases $\mathrm{CO}, \mathrm{H}_{2}$ $\mathrm{N}_{2} \mathrm{O}, \mathrm{NO}, \mathrm{CH}_{3} \mathrm{Cl}$ and COS, Nature, 282, 253-256, 1979.

Dee, D. P., Uppala, S. M., Simmons, A. J., Berrisford, P., Poli, P., Kobayashi, S., Andrae, U., Balmaseda, M. A., Balsamo, G., Bauer, P., Bechtold, P., Beljaars, A. C. M., van de Berg, L., Bidlot, J., Bormann, N., Delsol, C., Dragani, R., FUentes, M., Geer, A. J., Haimberger, L., Healy, S. B., Hersbach, H., Holm, E. V., Isaksen, L., Kallberg, P., Kohler, M., Matricardi, M., McNally, A. P., Monge-Sanz, B. M., Morcrette, J.-J., Park, B.-K., Peubey, C., de Rosnay, P., Tavolato, C., Thepaut, J.-N., and Vitart, F.: The ERA-Interim reanalysis: configuration and performance of the data assimilation system, Q. J. Roy. Meteorol. Soc., 137, 553597, 2011.

Emmons, L. K., Walters, S., Hess, P. G., Lamarque, J.-F., Pfister, G. G., Fillmore, D., Granier, C., Guenther, A., Kinnison, D., Laepple, T., Orlando, J., Tie, X., Tyndall, G., Wiedinmyer, C., Baughcum, S. L., and Kloster, S.: Description and evaluation of the Model for Ozone and Related chemical Tracers, version 4 (MOZART-4), Geosci. Model Dev., 3, 43-67, doi:10.5194/gmd3-43-2010, 2010.

Feingold, G., Remer, L. A., Ramaprasad, J., and Kaufman, Y. J.: Analysis of smoke impact on clouds in Brazilian biomass burning regions: An extension of Twomey's approach, J. Geophys. Res., 106, 22907-22922, 2001.

Fernandes, K., Baethgen, W., Bernardes, S., DeFries, R., DeWitt, D. G., Goddard, L., Lavado, W., Lee, D. E., Padoch, C., PinedoVasquez, M., and Uriarte, M.: North tropical Atlantic influence on western Amazon fire season variability, Geophys. Res. Lett., 38, L12701, doi:10.1029/2011GL047392, 2011.

Field, R. D., van der Werf, G. R., and Shen, S. S. P.: Human amplification of drought-induced biomass burning in Indonesia since 1960, Nature Geo., 2, 185-188, doi:10.1038/NGEO443, 2009.

Giglio, L., Randerson, J. T., van der Werf, G. R., Kasibhatla, P. S., Collatz, G. J., Morton, D. C., and DeFries, R. S.: Assessing variability and long-term trends in burned area by merging multiple satellite fire products, Biogeosciences, 7, 1171-1186, doi:10.5194/bg-7-1171-2010, 2010.

Granier, C., Lamarque, J. F., Mieville, A., Muller, J. F., Olivier, J., Orlando, J., Peters, J., Petron, G., Tyndall, G., and Wallens, S.: POET, a database of surface emissions of ozone precursors, available at: http://www.aero.jussieu.fr/projet/ACCENT/POET. php, 2005.

Grieshop, A. P., Logue, J. M., Donahue, N. M., and Robinson, A. L.: Laboratory investigation of photochemical oxidation of organic aerosol from wood fires 1: measurement and simulation of organic aerosol evolution, Atmos. Chem. Phys., 9, 1263-1277, doi:10.5194/acp-9-1263-2009, 2009.

Gunn, R. and Phillips, B. B.: An experimental investigation of the effect of air pollution on the initiation of rain, J. Meteor., 14, 272-280, doi:10.1175/15200469(1957)014;0272:AEIOTE; 2.0.CO;2, 1957.

Hansen, J., Sato, M., and Ruedy, R.: Radiative forcing and climate response, J. Geophys. Res., 102, 6831-6864, 1997.

Hansen, J., Ruedy, R., Sato, M., and Lo, K.: Global surface temperature change, Rev. Geophys., 48, RG4004, doi:10.1029/2010RG000345, 2010.

Held, I. M. and Soden, B. J.: Robust responses of the hydrological cycle to global warming, J. Clim., 19, 5686-5699, doi:10.1175/2010JCLI4045.1, 2006.

Holben, B. N., Eck, T. F., Slutsker, I., Tanre, D., p. Buis, J., Setzer, A., Vermote, E., Reagan, J. A., Kaufman, Y., Makajima, T., Lavenu, F., Jankowiak, I., and Smirnov, A.: AERONET - A federated instrument network and data archive for aerosol characterization, Remote Sens. Environ., 66, 1-16, 1998.

Johnston, F. H., Henderson, S. B., Chen, Y., Randerson, J. T., Marlier, M., DeFries, R. S., Kinney, P., Bowman, D. M. J. S., and Brauer, M.: Estimated global mortality attributable to smoke from landscape fires, Environ. Health Per., 120, 695-701, doi:10.1289/ehp.1104422, 2012.

Jones, A., Haywood, J. M., and Boucher, O.: Aerosol forcing, climate response and climate sensitivity in the Hadley Centre climate model, J. Geophy. Res., 112, D20211, doi:10.1029/2007JD008688, 2007.

Kaufman, Y. J., Fraser, R. S., and Mahoney, R. L.: Fossil fuel and biomass burning effect on climate-heating or cooling?, J. Climate, 4, 578-588, 1991.

Koren, I., Kaufman, Y. J., Remer, L. A., and Martins, J. V.: Measurement of the effect of Amazon smoke on inhibition of cloud formation, Science, 303, 1342-1345, doi:10.1126/science.1089424, 2004.

Koren, I., Kaufman, Y. J., Rosenfeld, D., Remer, L. A., and Rudich, Y.: Aerosol invigoration and restructuring of Atlantic clouds, Geophys. Res. Lett., 32, L14828, doi:10.1029/2005GL023187, 2005.

Lamarque, J.-F., Bond, T. C., Eyring, V., Granier, C., Heil, A., Klimont, Z., Lee, D., Liousse, C., Mieville, A., Owen, B., Schultz, M. G., Shindell, D., Smith, S. J., Stehfest, E., Van Aardenne, J., Cooper, O. R., Kainuma, M., Mahowald, N., McConnell, J. R., Naik, V., Riahi, K., and van Vuuren, D. P.: Historical (1850-2000) gridded anthropogenic and biomass burning emissions of reactive gases and aerosols: methodology and application, Atmos. Chem. Phys., 10, 7017-7039, doi:10.5194/acp10-7017-2010, 2010.

Lamarque, J.-F., Emmons, L. K., Hess, P. G., Kinnison, D. E., Tilmes, S., Vitt, F., Heald, C. L., Holland, E. A., Lauritzen, 
P. H., Neu, J., Orlando, J. J., Rasch, P. J., and Tyndall, G. K.: CAM-chem: description and evaluation of interactive atmospheric chemistry in the Community Earth System Model, Geosci. Model Dev., 5, 369-411, doi:10.5194/gmd-5-369-2012, 2012.

Langenfelds, R. L., Francey, R. J., Pak, B. C., Steele, L. P., Lloyd, J., Trudinger, C. M., and Allison, C. E.: Interannual growth rate variations of atmospheric $\mathrm{CO}_{2}$ and its $\delta^{13} \mathrm{C}, \mathrm{H}_{2}, \mathrm{CH}_{4}$, and $\mathrm{CO}$ between 1992 and 1999 linked to biomass burning, Global Biogeochem. Cy., 16, 1048, doi:10.1029/2001GB001466, 2002.

Lee, S., Kim, H. K., Yan, B., Cobb, C. E., Hennigan, C., Nichols, S., Chamber, M., Edgerton, E. S., Jansen, J. J., Hu, Y., Zheng, M., Weber, R. J., and Russell, A. G.: Diagnosis of aged prescribed burning plumes impacting an urban area, Environ. Sci. Technol., 42, 1438-1444, doi:10.1021/es7023059, 2008.

Liu, H. and Randerson, J. T.: Interannual variability of surface energy exchange depends on stand age in a boreal forest fire chronosequence, J. Geophys. Res., 113, G01006, doi:10.1029/2007JG000483, 2008.

Liu, X., Easter, R. C., Ghan, S. J., Zaveri, R., Rasch, P., Shi, X., Lamarque, J.-F., Gettelman, A., Morrison, H., Vitt, F., Conley, A., Park, S., Neale, R., Hannay, C., Ekman, A. M. L., Hess, P., Mahowald, N., Collins, W., Iacono, M. J., Bretherton, C. S., Flanner, M. G., and Mitchell, D.: Toward a minimal representation of aerosols in climate models: description and evaluation in the Community Atmosphere Model CAM5, Geosci. Model Dev., 5, 709-739, doi:10.5194/gmd-5-709-2012, 2012.

Lu, J., Vecchi, G. A., and Reichler, T.: Expansion of the Hadley cell under global warming, Geophys. Res. Lett, 34, L06805, doi:10.1029/2006GL028443, 2007.

Lu, J., Chen, G., and Frierson, D. M. W.: Response of the zonal mean atmospheric circulation to El Niño versus global warming, J. Climate, 21, 5835-5851, doi:10.1175/2008JCLI2200.1, 2008.

Lyons, E. A., Jin, Y., and Randerson, J. T.: Changes in surface albedo after fire in boreal forest ecosystem of interior Alaska assessed using MODIS satellite observations, J. Geophys. Res., 113, G02012, doi:10.1029/2007JG000606, 2008.

Mahowald, N., Ward, D. S., Kloster, S., Flanner, M. G., Heald, C. L., Heavens, N. G., Hess, P. G., Lamarque, J.-F., and Chuang, P. Y.: Aerosol impacts on climate and biogeochemistry, Annu. Rev. Environ. Resour., 36, 45-74, doi:10.1146/annurev-environ042009-094507, 2011.

Marlon, J. R., Bartlein, P. J., Carcaillet, C., Gavin, D. G., Harrison, S. P., Higuera, P. E., Joos, F., Power, M. J., and Prentice, I. C.: Climate and human influences on global biomass burning over the past two millenia, Nature Geosci., 1, 697-702, doi:10.1038/ngeo313, 2008.

Mitas, C. M. and Clement, A.: Has the Hadley cell been strengthening in recent decades?, Geophys. Res. Lett., 32, L03809, doi:10.1029/2004GL021765, 2005.

Morton, D. C., DeFries, R. S., Nagol Jr., J., C. M. S., Kasischke, E. S., Hurtt, G. C., and Dubayah, R.: Mapping canopy damage from understory fires in Amazon forests using annual time series of Landsat and MODIS data, Remote Sens. Environ., 115, 17061720, doi:10.1016/j.rse.2011.03.002, 2011.

Myhre, G., Govaerts, Y., Haywood, J. M., Berntsen, T. K., and Lattanzio, A.: Radiative effect of surface albedo change from biomass burning, Geophys. Res. Lett., 32, L20812, doi:10.1029/2005GL022897, 2005.
Neale, R. B., Chen, C.-C., Gettelman, A., Lauritzen, P. H., Park, S., Williamson, D. L., Conley, A. J., Garcia, R., Kinnison, D., Lamarque, J.-F., Marsh, D., Mills, M., Smith, A. K., Tilmes, S., Vitt, F., Morrison, H., Cameron-Smith, P., Collins, W. D., Iacono, M. J., Easter, R. C., Liu, X., and Taylor, M. A.: Description of the NCAR Community Atmosphere Model (CAM 5.0), Tech. rep., National Center for Atmospheric Research, 2010.

Neelin, J. D., Munnich, M., Su, H., Meyerson, J. E., and Holloway, C. E.: Tropical drying trends in global warming models and observations, P. Natl. Acad. Sci., 103, 6110-6115, doi:10.1073/pnas.0601798103, 2006.

Ohara, T., Akimoto, H., Kurokawa, J., Horii, N., Yamaji, K., Yan, X., and Hayasaka, T.: An Asian emission inventory of anthropogenic emission sources for the period 1980-2020, Atmos. Chem. Phys., 7, 4419-4444, doi:10.5194/acp-7-4419-2007, 2007.

Oort, A. H. and Yienger, J. J.: Observed interannual variability in the Hadley Circulation and its connection to ENSO, J. Climate, 9, 2751-2767, 1996.

Page, S. E., Siegert, F., Rieley, J. O., Boehm, H. D., Jaya, A., and Limin, S.: The amount of carbon released from peat and forest fires in Indonesia during 1997, Nature, 420, 61-65, doi:10.1038/nature01131, 2002.

Penner, J. E., Dickison, R. E., and O'Neill, C. A.: Effects of aerosol from biomass burning on the global radiation budget, Science, 256, 1432-1434, doi:10.1126/science.256.5062.1432, 1992.

Power, M. J., Marlon, J., Ortiz, N., Bartlein, P. J., Harrison, S. P., Mayle, F. E., Ballouche, A., Bradshaw, R. H. W., Carcaillet, C., and Cordova, C.: Changes in fire regimes since the Last Glacial Maximum: an assessment based on a global synthesis and analysis of charcoal data, Clim. Dyn., 30, 887-907, doi:10.1007/s00382-007-0334-x, 2008.

Quan, X.-W., Diaz, H. F., and Hoerling, M. P.: Change of the tropical Hadley cell since 1950, Kluwer Academic Publishers, 2005.

Ramanathan, V. and Carmichael, G.: Global and regional climate changes due to black carbon, Nature Geosci., 1, 221-227, doi:10.1038/ngeo156, 2008.

Ramanathan, V., Crutzen, P. J., Kiehl, J. T., and Rosenfeld, D.: Aerosols, climate, and the hydrological cycle, Science, 294, 2119-2124, 2001.

Randerson, J. T., Chen, Y., van der Werf, G. R., Rogers, B. M., and Morton, D. C.: Global burned area and biomass burning emissions from small fires, J. Geophys. Res., 117, G04012, doi:10.1029/2012JG002128, 2012.

Rasch, P. J., Collins, W. D., and Eaton, B. E.: Understanding the Indian Ocean Experiment (INDOEX) aerosol distributions with an aerosol assimilation, J. Geophys. Res., 106, 7337-7355, 2001.

Reid, J. S., Koppmann, R., Eck, T. F., and Eleuterio, D. P.: A review of biomass burning emissions part II: intensive physical properties of biomass burning particles, Atmos. Chem. Phys., 5, 799825, doi:10.5194/acp-5-799-2005, 2005.

Reid, J. S., Hyer, E. J., Prins, E. M., Westphal, D. L., Zhang, J., Wang, J., Christopher, S. A., Curtis, C. A., Schmidt, C. C., Eleuterio, D. P., Richardson, K. A., and Hoffman, J. P.: Global monitoring and forecasting of biomass-burning smoke: Description of and lessons from the Fire Locating and Modeling of Burning Emissions (FLAMBE) program, IEEE J. Appl. Earth. Obs. Rem. Sens., 2, 144-162, 2009. 
Rosenfeld, D.: TRMM observed first direct evidence of smoke from forest fires inhibiting rainfall, Geophys. Res. Lett., 26, 3105, doi:10.1029/1999GL006066, 1999.

Rosenfeld, D.: Aerosols, clouds, and climate, Science, 312, 13231324, doi:10.1126/science.1128972, 2006.

Rosenfeld, D., Woodley, W. L., Axisa, D., Freud, E., Hudson, J. G., and Givati, A.: Aircraft measurements of the impacts of pollution aerosols on clouds and precipitation over the Sierra Nevada, J. Geophys. Res., 113, D15203, doi:10.1029/2007JD009544, 2008.

Sitch, S., Cox, P. M., Collins, W. J., and Huntingford, C.: Indirect radiative forcing of climate change through ozone effects on the land-carbon sink, Nature, 448, 791-794, doi:10.1038/nature06059, 2007.

Spessa, A., McBeth, B., and Prentice, C.: Relationships among fire frequency, rainfall and vegetation patterns in the wet-dry tropics of northern Australia: an analysis based on NOAAAVHRR data, Global Ecology and Biogeography, 14, 439-454, doi:10.1111/j.1466-822x.2005.00174.x, 2005.

Swetnam, T. W. and Betancourt, J. L.: Mesoscale disturbance and ecological response to decadal climatic variability in the American Southwest, J. Climate, 11, 3128-3147, 1998.

Tosca, M. G., Randerson, J. T., Zender, C. S., Flanner, M. G., and Rasch, P. J.: Do biomass burning aerosols intensify drought in equatorial Asia during El Niño?, Atmos. Chem. Phys., 10, 35153528, doi:10.5194/acp-10-3515-2010, 2010.

Tosca, M. G., Randerson, J. T., Zender, C. S., Nelson, D. L., Diner, D. J., and Logan, J. A.: Dynamics of fire plumes and smoke clouds associated with peat and deforestation fires in Indonesia, J. Geophys. Res., 116, D08207, doi:10.1029/2010JD015148, 2011.

Turetsky, M. R., Kane, E. S., Harden, J. W., Ottmar, R. D., and Manies, K. L.: Recent acceleration of biomass burning and carbon losses in Alaskan forests and peatlands, Nature Geosci., 4, $27-$ 31, 2011.

Val Martin, M., Logan, J. A., Kahn, R. A., Leung, F.-Y., Nelson, D. L., and Diner, D. J.: Smoke injection heights from fires in North America: analysis of 5 years of satellite observations, Atmos. Chem. Phys., 10, 1491-1510, doi:10.5194/acp-10-14912010, 2010. van der Werf, G. R., Dempewolf, J., Trigg, S. N., Randerson, J. T., Giglio, L., Murdiyarso, D., Peters, W., Morton, D. C., Collatz, G. J., Dolman, A. J., and DeFries, R. S.: Climate regulation of fire emissions and deforestation in equatorial Asia, P. Natl. Acad. Sci., 105, 20350-20355, doi:10.1073/pnas.0803375105, 2008.

van der Werf, G. R., Randerson, J. T., Giglio, L., Collatz, G. J., Mu, M., Kasibhatla, P. S., Morton, D. C., DeFries, R. S., Jin, Y., and van Leeuwen, T. T.: Global fire emissions and the contribution of deforestation, savanna, forest, agricultural, and peat fires (19972009), Atmos. Chem. Phys., 10, 11707-11735, doi:10.5194/acp10-11707-2010, 2010.

Wang, H., Easter, R. C., Rasch, P. J., Wang, M., Liu, X., Ghan, S. J., Qian, Y., Yoon, J.-H., Ma, P.-L., and Velu, V.: Sensitivity of remote aerosol distributions to representation of cloud-aerosol interactions in a global climate model, Geosci. Model Dev. Discuss., 6, 331-378, doi:10.5194/gmdd-6-331-2013, 2013.

Ward, D. S., Kloster, S., Mahowald, N. M., Rogers, B. M., Randerson, J. T., and Hess, P. G.: The changing radiative forcing of fires: global model estimates for past, present and future, Atmos. Chem. Phys., 12, 10857-10886, doi:10.5194/acp12-10857-2012, 2012.

Westerling, A. L., Hidalgo, H. G., Cayan, D. R., and Swetnam, T. W.: Warming and earlier spring increase western U.S. forest wildfire activity, Science, 313, 940-943, doi:10.1126/science.1128834, 2006.

Xian, P., Reid, J., Turk, J., Hyer, E., and Westphal, D.: Impact of modeled versus satellite measured tropical precipitation on regional smoke optical thickness in an aerosol transport model, Geophys. Res. Lett., 36, L16805, doi:10.1029/2009GL038823, 2009.

Yoshimori, M. and Broccoli, A. J.: On the link between Hadley circulation changes and radiative feedback processes, Geophys. Res. Lett., 36, L20703, doi:10.1029/2009GL040488, 2009.

Zhang, Y., Fu, R., Yu, H., Qian, Y., Dickinson, R., Dias, M. A. F. S., da Silva Dias, P. L., and Fernandes, K.: Impact of biomass burning aerosol on the monsoon circulation transition over Amazonia, Geophys. Res. Lett., 36, L10814, doi:10.1029/2009GL037180, 2009. 